\title{
Tyrkiet og Grækenland er integrerede dele af Balkan
}

Uffe Østergård

Fælles for landene på Balkan, inklusive Tyrkiet og Balkan, er en arv fra det Byzantinske og det

Osmanniske Rige. Det er i denne historiske arv, man skal søge baggrunden for de fælles træk, der karakteriserer denne del af Europa, som i dag synes at leve op til de værste fordomme. Men der er andre potentialer i historien

Balkan er en betegnelse der blev skabt af geografer i begyndelsen af 1800-tallet som en parallel til den Pyrenæiske Halvø for Spanien og Portugal og den Appenninske Halvø for Italien. Ofte nævnes den tyske geograf A. Zeun (1778-1843) som ophavsmand til navnet i et skrift fra 1808. Balkan-halvøen omfatter området mellem Adriaterhavet, det Joniske Hav, det Ægæiske Hav, Marmarahavet og Sortehavet og afgrænses mod nord af floderne Donau og Sava og i vest af en linje mellem Ljubljana og Trieste, et område med næsten 50 millioner indbyggere og en befolkningstæthed noget over gennemsnittet i det øvrige Europa.
Det omfatter de nuværende stater Kroatien, Bosnien-Hercegovina, Montenegro, Serbien, Albanien, Makedonien, Bulgarien, Grækenland (minus øerne) samt den europæiske del af Tyrkiet.

Slovenien som var en del af det tidligere Jugoslavien, regnedes indtil 1990 ofte med til 'Balkan', men må i dag med indførelsen af euroen og et succesfuldt EU-formandskab endegyldigt siges at tilhøre den mere positivt opfattede kategori 'Centraleuropa'. Til gengæld må Rumænien regnes som et Balkanland, selv om det geografisk ligger nord for floden Donau. Derimod giver det hverken geografisk eller historisk mening at 
regne Ungarn med. To tredjedel af Ungarn var ganske vist i næsten to hundrede år underlagt tyrkerne en episode, der forbigås i total tavshed på museerne i Budapest. Men det er en misforståelse at regne dette centraleuropæiske land med til Balkan, blot fordi sproget forekommer svært - det er finno-ugrisk, om end uforståeligt for finsk og estisk talende - eller fordi landet gennemløber en svær økonomisk og politisk krise i disse år.

Navngivningen 'Balkan' beroede på en fejlagtig forestilling om eksistensen af en ubrudt bjergkæde, som rejsende fra Centraleuropa til Istanbul måtte passere. Reelt er der tale om adskilte bjergområder med højsletter og brede dalstrøg imellem, først og fremmest Makedonien der ligger midt i Balkan. Herfra kan man dominere de omliggende lande og kontrollere hovedindfaldsvejen fra Thessaloniki i Grækenland til Donau-bassinet. Det var her de allierede under Første Verdenskrig kæmpede indædt, men uden større succes, i flere år for at rette et stød mod Østrig-Ungarn og undsætte det erobrede Serbien.

Makedoniens geografi er forklaringen på at alle naboer, fra bulgarerne og serberne til grækerne og albanerne har gjort og til dels stadig gør krav på dette ulyksalige område, samtidig med at navnet er forbundet med alle tiders største erobrer Alexander den Store, hans fader Filip og hans makedonske efterføl- gere, der herskede over en del af arven efter Alexander - de andre var ptolemæerne i Ægypten og seleukiderne i Syrien, Mesopotamien og Iran.

'Balkan' er imidlertid ikke en neutral geografisk kategori, men er blevet selve kodeordet for opløsning, skumle intriger og uhæmmet blodtørst som det fremgår af den bulgarsk-amerikanske historiker Maria Todorovas fascinerende analyse, Imagining the Balkans fra 1997. Denne forståelse af 'Balkan' er populariseret i udødelige klassikere der er filmatiseret igen og igen. Det drejer sig om Bram Stokers Dracula fra 1897 , selv om bogen strengt taget foregår i Transsylvanien, der indtil 1918 var en central del af Ungarn; Anthony Hopes drengebogsklassiker Fangen på Zenda fra 1899, der foregår i et ubestemt land ved navn 'Ruritanien', en betegnelse der siden er slået i den grad an i angelsaksisk sprogbrug at historikeren E. J. Hobsbawm til undren for generation efter generation af geografisk ukyndige læsere henviser til dette land i sin klassiker, Nations and Nationalism fra 1990.

Allermest medvirkende til at udødeliggøre myten om det mystiske 'Balkan' er formodentlig Agatha Christies krimi, Mordet $i$ Orient-ekspressen fra 1934 og - måske især for en ældre generation - Eric Amblers talrige spionromaner fra et Balkan mellem nationalisme, international våbenhandel $\mathrm{og}$ autoritær kommu- 
nisme oven på en undergrund af uigennemsigtige 'byzantinske' politiske intriger, korruption og vold.

Hvordan det nu end forholder sig med disse litterære klassikere, om de var årsag eller virkning, kom ordet 'balkanisering' efter $1880 \mathrm{i}$ takt med opløsningen af det Osmanniske Imperium og oprettelsen af mere eller mindre nationale stater til at blive et synonym for opløsning i stridende småstater.

På italiensk bruges en konkurrerende, men endnu mere politisk ukorrekt betegnelse, 'macedonia' som er navnet på en frugtsalat. Dermed hentydes til de mange, småt skårne frugtstykker der er blandet med hinanden i stil med de nationale og etniske grupper der lever side om side på Balkan. Den nationalt blandede situation er et resultat af situationen i det Osmanniske Rige, hvor grupper defineredes efter religion.

I 1800-tallet blev religiøse grupper efterhånden identificeret som nationaliteter med de deraf følgende blodige konflikter mellem nært beslægtede folkeslag og naboer, som vi senest var vidne til i borgerkrige i Jugoslavien i 1990'erne. Det Osmanniske Rige var et sammensat imperium, der på sit højdepunkt i 1500og 1600-tallet strakte sig over hele det Mellemste Østen, Egypten, Nordafrika og det område i Europa der i politisk korrekt EU-newsspeak kaldes 'Syd- og Sydøsteuropa' - hvor det lades uafklaret om Grækenland som medlem af EU siden 1981 hører med til Balkan. Navnet skyldes grundlæggeren af det herskende dynasti, Osman.

\section{Mytedannelse}

Betegnelsen det 'Osmanniske Rige' svarer til det 'Habsburgske Imperium' der også var navngivet efter det herskende dynasti. Eller det 'Oldenborgske Monarki' mellem 1460 og 1863, der er den rette titel på den dansk-norsk-slesvigsk-holstenske sammensatte helstat med områder i Nordatlanten samt kolonier i Afrika, Vestindien og Indien.

$\mathrm{Al}$ geografi og moderne fordomsfuld mytedannelse til side er det dog især den fælles arv fra de fem århundrede hvor Balkan under navnet Rumeli var en central del af det Osmanniske rige samt den ortodokse udgave af kristendommen der stammede fra det Østromerske eller Byzantinske Rige, der er særkendet for denne del af Europa. Denne er blevet forvaltet af forskellige autoritære, mere eller mindre nationalistiske regimer i 1800- og 1900-tallet.

Siden kom hele området, bortset fra Grækenland, under forskellige diktatoriske kommunistiske regimer. I Grækenland sejrede de konservative kræfter i en forbitret borgerkrig mellem 1944 og 1949 med vestlig hjælp, men blev ikke meget mindre autoritært og byzantinsk, blot med modsat politisk fortegn. Selv om det ikke gøres ret ofte, bør Tyrkiet i 
grunden også medregnes til Balkan af historiske såvel som geografiske årsager. Også dette land var nationalistisk og autoritært styret, blot på islamisk grundlag. Af den grund undgik landet kommunismen og tilsluttede sig i stedet den vestlige alliance.

Arven fra det Byzantinske eller Østromerske Rige er i foråret 2010 tema for en udstilling i Rundetån og en bog fra forlaget Sfinx redigeret af Byzans-kenderen Karsten Fledelius. Dermed menes den statsdannelse der med hovedstad i Konstantinopel, tidligere Byzans, hvoraf betegnelse, var en langvarig statsdannelse i den østlige del af Middelhavet som overlevede Romerrigets undergang i over tusinde år.

Alligevel fremstilles landet traditionelt lige siden Edward Gibbons indflydelsesrige værk fra 1776-78 som én lang undergangshistorie under overskriften History of the Decline and Fall of the Roman Empire. Det er misforstået, og statsdannelsen bør i stedet forstås i sin egen ret som en af de store epoker i europæisk kulturhistorie.

Fra begyndelsen af vores tidsregning beherskede romerne hele Balkan-halvøen. Den befæstede grænse, limes, fulgte længe floden Donau, men romersk indflydelse strakte sig langt på den anden side af floden, og Balkan-halvøen blev tæt integreret i det romerske administrative system. Især under kejser Diokletians styre i begyndelsen af 200-tallet hvor han styrede hele det vidtstrakte Romerske Rige fra sin hovedstad i Split, hvor hans kolossale palads stadig er bevaret og udgør byens centrum. Romerne anlagde veje, byer og garnisoner over hele området i en frugtbar syntese mellem græsk og romersk kultur der i stigende grad udforskes i disse år.

Under kejser Trajan i 100-tallet erobrede romerne Dacien, det vil sige store dele af vore dages $\mathrm{Ru}-$ mænien. Den blandingskultur, og især det blandingssprog der kom ud af det, har det moderne Rumænien siden 1800-tallet brugt til at understrege forskellene til de omgivende såkaldt 'slaviske' befolkninger, idet de fremhæver deres eget sprogs 'latinske' karakter.

Reelt er den slaviske indflydelse i rumænsk dog meget større end rumænske ideologer vil indrømme. Grammatikken er ubetvivleligt latinsk, men trods gentagne sprogrensninger er ordforrådet langt mere fælles med de slaviske naboers end ideologien tilsiger. $\mathrm{Og}$ så sent som i 1600-tallet blev rumænsk skrevet med kyrilliske bogstaver på linje med de omgivende slaviske sprog.

\section{Det østromerske rige}

Efter delingen af det Romerske Rige i 395 kom det meste af Balkan under det Østromerske Rige. Det er sidenhen kommet til at gå under navnet det Byzantinske Rige efter navnet på den græske by ved Bosporus 
Strædet som kejser Konstantin omdannede til sin hovedstad i 300-tallet, Konstantinopel der betyder Konstantins polis. Grænseområderne nord og syd for Donau blev under folkevandringerne invaderet først af østgoterne og siden i 600-tallet af slavisk talende folkeslag. Samtidig blev Byzans trængt fra øst, først af Sassaniderne i Persien, siden af de hastigt ekspanderende arabere $\mathrm{i}$ 700-tallet.

Den alvorligste trussel kom dog fra bulgarerne der etablerede et stærkt rige nord for Byzans i 800-tallet. I den proces blev de slaviske folk grundlæggende præget af den højt udviklede græsk-byzantinske civilisation, først og fremmest i kraft af deres omvendelse til kristendommen i den østlige udgave. Det begyndte med brødrene Kyrillos (ca. 826/27869) og Methodios (ca. 815-885) der kaldes de slaviske folks apostle.

Begge brødre blev født i Thessaloniki i den nordlige del af Grækenland. Her fik Kyrillos, med fødenavnet Konstantinos, en solid teologiskfilosofisk uddannelse og løste diplomatiske opgaver for den byzantinske kejser. Derfor blev Kyrillos i 862 sendt til Moravien (et stort rige der blandt andet omfattede vore dages Tjekkiet og Slovakiet) hvis fyrste havde bedt om missionærer.

Til dette formål udarbejdede Kyrillos det såkaldte glagolitiske eller kyrilliske alfabet og oversatte liturgien og dele af Bibelen til oldslavisk, det sprog som i dag kendes som kir- keslavisk. Brødrenes indsats stødte imidlertid på kraftig modstand fra den romerske kirke der også missionerede i disse egne. Efterhånden fik Romerkirken i en kompliceret samvirken med kejseren i det Hellige Romerske Rige (på latin Sacrum Imperium) der ikke kun var tysk, overtaget i Centraleuropa og Kroatien, ligesom den fik det i Skandinavien og Polen i løbet af 800- og 900-tallet. Methodios' og Kyrillos' medarbejdere slog sig i stedet efter apostlenes død ned i det Bulgarske Rige hvor de udviklede den kirkeslaviske tradition, som lige siden har blomstret med basis i de store klostre her og i Grækenland samt i Serbien og Kosovo.

Kyrillos' og Methodios' indsats værdsættes stadig højt i de slaviske ortodokse lande. Således er universitetet i Veliko Tarnovo i Bulgarien opkaldt efter dem. Det kyrilliske alfabet der kan minde om det græske, bruges stadig i mange af Balkan-landene, først og fremmest Serbien, Makedonien, Montenegro og Bulgarien.

Men det Byzantinske Rige svækkedes stadig mere, især efter det fjerde korstog i 1204 som førte til plyndringen af Konstantinopel og indsættelsen af en latinsk kejser. Det gav til gengæld rum for opkomsten af en række middelalderlige statsdannelser på Balkan, især de bulgarske, bosniske og serbiske kongeriger.

Men alle disse riger er grundlæggende præget af arven fra det sær- 
egne byzantinske eller østromerske rige der har medført en række træk i den politiske kultur i Balkan-staterne der ofte sammenfattes under overskriften 'byzantinsk'.

\section{Skismaet mellem øst- og vestkirke}

Kristendommen omtales ofte i ental, men i virkeligheden har det mest karakteristiske for denne religion næsten fra starten været splittelse mellem forskellige fortolkninger af de hellige skrifter. Fortolkninger der i mange tilfælde har fået organisatoriske udslag, således at kristendommen består af mange kirker. Den hos os i Nordeuropa bedst kendte splittelse er resultatet af reformationen i 1500-tallet der førte til oprettelse af de lutherske fyrstekirker og forskellige calvinistisk-presbyterianske kirker på den ene side og en nyformulering af den overnationale katolske kirke gennem modreformationen på den anden side. Ser man på hele kristendommens udvikling, er de teologiske forskelle mellem katolikker og protestanter dog langt mindre dybtgående end mange af de tidligere splittelser.

I dag er især den koptiske kirke i Egypten samt den etiopiske kirke og den kristne i Sydindien monofysiter, mens flertallet af de øvrige kristne kirker holder fast i det klassiske kompromis om treenigheden fra kirkemøderne (synoderne) i Nikæa 325 og Kalkedon 451. Grunden til at følgerne af de teologiske diskussio- ner blev så store for hele samfundet var at kristendommen efter Konstantin den Store blev eneste tilladte statsreligion i det verdensomspændende Romerske Imperium.

Konsekvenserne af den overraskende ophøjelse af en mellemøstlig minoritetsreligion til statsreligion kan ikke overvurderes. Forløbet er en spændende historie i sig selv, som det vil føre for vidt at referere her, så jeg må nøjes med at henvise til den glimrende skildring i trebindsværket Imperium Romanum (Due og Isager 1993). I denne politisk-kulturelle sammenhæng er det afgørende at religiøse diskussioner efter at kristendommen var blevet statsreligion, antog karakter af statsanliggender som kejseren og hans embedsmænd engagerede sig i. I perioder har man ligefrem indtryk af at teologiske diskussioner var vigtigere for de østromerske kejsere end krig og udenrigspolitik. Det skyldtes at kejseren i øst ikke blot var verdsligt, men også religiøst overhoved. Man kalder normalt denne opfattelse af magtforholdene for casareopapisme.

I takt med adskillelsen mellem den østlige og den vestlige del af det romerske imperium samledes nemlig mere og mere magt i den byzantinske kejser og hans embedsmænds hænder. I begyndelsen var kirken det eneste samfundsområde hvor kejsermagten undertiden stødte på grænser. Kejser Justinian i midten af 500-tallet og hans efterfølgere iden- 
tificerede den ortodokse kejser, dvs. staten, med den ortodokse kirke.

\section{Treenigheden}

I Nikæa vedtoges den såkaldte nikæansk-konstantinopolitanske trosbekendelse om Gud som en treenighed af Faderen, Helligånden og sønnen i 325 . Denne bekendelse blev siden præciseret på den anden $ø \mathrm{ku}-$ meniske synode i Konstantinopel i 381. Som kirkehistorikeren Leif Grane skriver i sin kirkehistoriske oversigt fra 1973 kan det være vanskeligt for mennesker i dag, selv teologisk trænede, at forstå betydningen af de stridigheder om formuleringer om Guds natur der optog sindene så voldsomt i 300-tallet. Det skyldes at vi ikke deler deres filosofiske forudsætninger i den græske tænkning. Men selv om diskussionen handlede om subtile begreber, var det for 300tallets mennesker deres liv og frelse der stod på stil.

Men dette politiske kompromis tilfredsstillede ikke de forskellige kirker i øst, og diskussionen fortsatte i de følgende år. Resultatet blev en stadig skiftende kejserlig politik for at stille snart den ene snart den anden retning tilfreds. Det kan virke underligt at hensynet til den rene lære, 'Kalkedon-ortodoksien', blev sat over truslen udefra fra germanere, slaver, persere, arabere og til sidst tyrkerne. Men sådan var det.

I Vesten hvor den teologisk-filosofiske interesse i disse århundreder var mindre sofistikeret, var kompromiset i Kalkedon derimod et tilstrækkeligt svar. Hermed blev grunden lagt til den splittelse mellem øst- og vest-kristendommen som førte til det store skisma i 1054. Men det er vigtigt at erindre at de to kirker indtil da i princippet arbejdede på samme dogmemæssige grundlag.

Hovedårsagen til splittelsen mellem øst- og vest-kristendom skal søges i politiske og kulturelle følger af udviklingen af en latinsk og en græsk kirke og disses interesser i kejsermagten i øst og vest, en forskel der kulminerede med det fjerde korstog og den latinske erobring af Konstantinopel i 1204.

For Osmannerne udgjorde det slavisk-ortodokse Balkan og de græsk talende områder kernelandet sammen med det efterhånden tyrkisk talende og muslimske Lilleasien. Caesareopapismens autoritære traditioner havde i de foregående århundreder slået rod blandt de slaviske folkeslag på Balkan og overlevede under det osmanniske herredømme. Ja styrkedes nærmest.

Onde tunger vil sige at denne tradition siden indgik en symbiose, først med de nationalistiske regimer i 1800-tallet og mellemkrigstiden og siden efter Anden Verdenskrig med de nationale kommunistiske styrer i flere af landene, især Todor Sjivkovs Bulgarien, Nicolae Ceaucescus enevældige diktatur i Rumænien og delvis i Titos Jugoslavien. Uanset om man vil gå så vidt, er der meget som 
tyder på at det er relevant at tale om en særlig ortodoks politisk kultur med stærke byzantinske træk, en politisk kultur der forklarer mange særtræk i landene på Balkan såvel som i Rusland og i mange af de tidligere sovjetiske stater.

Selv om man kan argumentere for at mange træk fra det Byzantinske Rige reelt fortsatte i det Osmanniske Rige efter 1453, trods skiftet i dominerende religion fra ortodoks kristendom til islam, er det dog ubetvivleligt at Balkan-landene i dag først og fremmest er præget af arven fra de mange århundreder under tyrkisk herredømme. Karakteren af dette herredømme er der til gengæld ingen enighed om, hverken i forskning eller politik.

\section{Arven fra det Osmanniske Rige}

Den moderne tyrkiske stat er en efterfølgerstat til det Osmanniske Imperium på samme måde som Grækenland, Bulgarien, Rumænien, Serbien, Montenegro, Makedonien og Albanien. Men Tyrkiet identificeres normalt alene med al ineffektivitet og grusomhed i det Osmanniske Imperium. Som når man tidligere ville skræmme børnene til at sove med ordene 'ellers tager tyrken dig'.

Billedet af et truende, asiatisk Tyrkiet fremmanes ofte i europæiske offentligheder, et billede af et land der på samme tid er geografisk nært og dog uendelig fjernt, islamisk og asiatisk. Det er der en lang tradition for. De europæiske forestillinger om Europa opstod nemlig akkurat i kraft af den tyrkiske ekspansion. Al kollektiv identitetsdannelse forudsætter eksistensen af en såkaldt 'signifikant anden'. Og denne 'anden' blev for Europa tyrkerne der opfattedes som den største trussel mod det kristne Europa. Tyrkerne blev i den litterære og efterhånden også folkelige offentlighed identificeret med alt ondt, ukristeligt og ikke-europæisk. Fjendebilledet af det Osmanniske Rige som den store trussel mod Europa er i den folkelige forståelse forstærket af de grusomheder der uafviseligt blev begået under opløsningen i 1800- og 1900-tallet. Men den grusomme adfærd i rigets sidste hundrede år var ikke karakteristisk for hele dets lange historie.

Det begyndte i Lilleasien, hvor den tyrkiske feudale høvding Osman 1. der levede fra 1281 til 1326 i 1301 grundlagde en lille røverstat på grænsen mellem det svækkede byzantinske rige og seldsjukkerne $\mathrm{i}$ Konya. Vestanatolien havde udgjort et magtvakuum siden midten af 1200-tallet, idet Byzans var knækket af tyrkerne og den latinske erobring under det fjerde korstog i 1204.

De nominelle herskere over Lilleasien var mongolerne, men de udøvede ingen effektiv kontrol, lige så lidt som de kristne kejsere gjorde, selv efter at de havde generobret Konstantinopel i 1261. Langs den byzantinsk-seldsjukiske grænse opstod en række småriger, hvor stor- 
mænd samlede muslimske krigere rekrutteret blandt de tyrkiske hyrder omkring sig. I starten var Osmans organisation det mindste af disse småriger, der legitimerede deres overfald på de kristne ud fra islams forestillinger om jihad, hellig krig. Krigerne opfattedes som gazi, professionelle trosforkæmpere.

Det afgørende gennembrud for osmannerne skete, da de anførte de anatolske tyrkeres invasion af Balkan i 1353. Tyrkiske hære under osmannisk ledelse erobrede i de følgende tiår næsten alle Byzans' europæiske besiddelser bortset fra området inden for Konstantinopels stærke mure. Mellem 1371 og 1396 faldt ikke blot de relativt svagt forsvarede byzantinske område, men også militært stærke, feudale riger som Bulgarien og Serbien i et forbløffende tempo.

Balkan-staternes tungt udrustede ridderhære blev totalt slået af det osmanniske infanteri i samarbejde med let kavaleri. Det samme skete for de vesteuropæiske ridderhære der forsøgte at komme deres kristne trosfæller til undsætning. Mest dramatisk i slaget ved Nikopolis i 1396 i det nordlige Bulgarien, hvor en vestlig korsfarerhær under ledelse af den ungarske konge og senere kejser, Sigismund, blev udslettet.

Et af de mest skæbnesvangre slag $i$ denne serie af kristne nederlag var det serbiske riges undergang på slagmarken Kosovo Polje (solsortesletten) i 1389. Serberne mindes sta- dig dette nederlag, og det var Slobodan Milosevic' storstilede nationalistiske festligheder i anledning af 600-års jubilæet for nederlaget til de tyrkiske arvefjender i 1989, der blev indledning til den serie af ulyksalige begivenheder der resulterede i den brutale opløsning af Jugoslavien.

Begivenhederne i Jugoslavien demonstrerede betydningen af de udbredte mytologiske og forvrængede opfattelser af fortiden på Balkan. Næsten alle dagens modsætninger mellem Tyrkiet og Grækenland, mellem Bulgarien og Tyrkiet, mellem serbere og muslimske bosniaker, mellem serbere og albanere, mellem kroater og serbere osv. har deres mytiske rod i begivenheder under det Osmanniske Rige.

Erobringerne indebar nederlag for de kristne, feudale statsdannelser og sejr for det universalistiske tyrkisk-muslimske imperium. Men også alle de gensidige misforståelser går tilbage til denne periode. Det begivenhedsforløb de kristne i hvert fald siden hen har opfattet som grusomt asiatisk despoti og muslimsk religionskrig, opfattede tyrkerne og de øvrige muslimer på Balkan og i Anatolien - og opfatter delvis stadig - som udskiftningen af ét universelt kejserrige, det Østromerske, med et andet, det Osmanniske. Hvor kristne europæere i hvert fald fra slutningen af 1700-tallet har talt om muslimsk undertrykkelse og religiøs fanatisme, husker tyrkerne den relative fred og stabilitet, som 'deres' 
rige medførte på begge sider af skillelinjen mellem Europa og Asien.

\section{Europæisk karakter}

I realiteten var det tyrkiske rige senest fra 1362 en europæisk stat med hovedstad i Adrianopel (Edirne) på den europæiske side af stræderne.

At staten nu havde sin vigtigste basis i Europa blev demonstreret af hændelserne efter nederlaget til en mongolsk invasionshær under Timur Lenk ved Ankara i 1402. Sultan Bajazet 1. blev slået og taget til fange med hele sin hær efter et blodigt slag, der først blev afgjort, da højre flankes asiatiske kontingenter gik over til mongolerne efter at have set at krigslykken gik deres osmanniske hersker imod. Venstre flanke bestående af styrker fra Anatolien og 'europæiske' tropper fra Balkan, især serbere, kæmpede derimod ifølge Timur Lenk 'som løver'.

Nederlaget var tæt på at få det Osmanniske Rige til at bryde sammen. De anatolske vasaller skyndte sig at generobre deres uafhængighed under Den høje Ports svaghed efter sultanens tilfangetagelse og efterfølgende død. Men de europæiske besiddelser forblev loyale. Tilsyneladende var Balkans bondebefolkninger tilfredse med deres relativt tolerante nye herrer der gav dem lov at benytte deres eget sprog, praktisere deres egne love og udøve deres egen religion. Bare de betalte skat. Det var først og fremmest serbernes loyalitet der tillod de osmanniske sultaner at bringe riget på fode og genoptage ekspansionspolitikken, først mod Ungarn siden mod Konstantinopel.

Første fase af denne plan blev fuldført med erobringen af Konstantinopel 29. maj 1453. Sultan Mehmet 2. fik i den anledning tilnavnet Fatih, erobreren, og opfattede sig desuden som kaysar-i-Rûm, dvs. kejser af Byzans (det andet Rom). Fra denne basis udgik en ny mægtig erobringsbølge. 1459 underlagde Mehmet 2. sig Serbien med undtagelse af Beograd (en del af Serbien var som tidlige anført allerede blevet erobret i 1389 efter slaget på Solsortesletten i Kosovo); 1464 erobrede han Bosnien og 1467 Hercegovina. Erobringen gik nemt, da den lokale overklasse, hvad enten den var ortodoks eller bogumilsk, foretrak de religiøst tolerante tyrkiske herskere frem for det katolske alternativ. Bogumiler betyder på slavisk 'Guds elskede'; det var navnet på en særlig kristen sekt i Bosnien, der blev forfulgt som kættere af både den ortodokse og den katolske kirke.

Det er blevet hævdet at bogumilerne var dualister ligesom katarerne i Sydfrankrig, og derfor religiøst nærmere islam. Det er sandsynligvis forkert, men uanset hvordan forholdet var mellem bogumiler og islam, er det givet at de religiøse forhold, især afsky over den katolske kirkes brutale fremfærd mod de ortodokse kristne var vigtige betingelser for 
islams fremgang i Bosnien. I det omfang bondebefolkningerne blev spurgt, foretrak de så absolut de tyrkiske skatteopkrævere der opkrævede en fast takst, frem for deres egne lunefulde feudalherrer som havde skruet kravene op år for år for at kunne føre krig mod tyrkerne.

Efter et mellemspil hvor Selim 1. mellem 1514 og 1517 erobrede Irak, Kurdistan, Syrien, Palæstina og Egypten med Nordafrika kom turen til Centraleuropa. Selims søn, Suleiman 1., erobrede i 1521 den ungarske grænsefæstning Beograd og indledte derfra felttoget mod Ungarn. I 1526 besejrede han Lajos 2. af Ungarn og Bøhmen ved Mohács i det sydøstlige Ungarn.

Den unge konge faldt i spidsen for sin hær, og arvekravet på de to kongedømmer overgik til ærkehertug Ferdinand af Østrig. Denne krævede nu foruden Bøhmen herredømmet over det resterende Ungarn sammen med Kroatien, der havde været i personalunion med Ungarn siden 1102, i tillæg til sine habsburgske arvelande omkring Wien (Nedre og $\emptyset_{\text {vre }} \emptyset_{\text {strig, Tyrol, }}$ Steiermark, Kärnten og Krain - de to sidste udgør det nuværende Slovenien, mens resten stort set svarer til Østrig, bortset fra Sydtyrol, der tilhører Italien siden 1919).

De kroatiske adelige valgte i 1527 Ferdinand til konge, især fordi han i deres øjne besad den store kvalitet ikke at være magyar. Flertallet af de magyariske adelige accepterede imidlertid ikke Ferdinand, og de næste 200 år var præget af strid mellem habsburgerne og forskellige magyariske tronprætendenter. Disse sidste anerkendte i forskellig grad sultanen i Istanbul som deres øverste herre, hvorved billedet af en absolut frontdannelse mellem kristne habsburgere og muslimske tyrkere i nogen grad fortoner sig.

Under en serie krige mellem 1697 og 1718 erobrede det habsburgske dynastis hære under den fremragende general prins Eugen af Savoyen Ungarn og dele af Balkan fra tyrkerne og lagde grunden til en national vækkelse blandt osmannernes kristne undersåtter.

\section{Moderne og tolerant}

Indtil engang i 1700-tallet var det Osmanniske Rige på mange måder den mest moderne og tolerante stat i Europa. Det har været svært for europæerne at indrømme, og billedet er heller ikke trængt igennem uden for speciallitteraturen. Men faktisk kan man selv overbevise sig om den europæiske karakter af den ældre tyrkiske kultur ved at studere moskéerne i Istanbul. Som bygningsværker er de selvfølgelig fremmedartede for os med det kvadratiske rum og de to, fire eller seks minareter udenfor.

Denne fremmedartethed forstyrres ikke af det faktum at en af de mest fremtrædende moskéer, Hagia Sofia ved sin opførelse i 300-tallet 
var en af de fire vigtigste kirker i kristenheden (ved siden af Jerusalem, Antiochia og Trier - Peterskirken i Rom blev først dominerende temmelig sent). Ser man nøjere efter, viser det sig imidlertid at disse 'typiske' islamiske, tyrkiske bygningsværker repræsenterer de forskellige europæiske arkitekturretninger, som toscansk renæssance, barok og sågar nyklassicisme.

Årsagen er den enkle at arkitekterne var indforskrevne europæere - eller kristne bondesønner fra Balkan som arkitekten Sinan (14891588). De medbragte det sidste og nyeste i vestlig bygningsteknik fra det Italien og Frankrig som osmannerne stod i nær forbindelse med. Det vil sige at den europæiske kristenheds fjende par excellence i realiteten stod i tæt kulturel udveksling med hovedfjenden.

Det er ikke kun i Sarajevo at man kan (eller rettere kunne) møde islamisk kultur i europæisk aftapning. Det samme gjorde sig gældende inden for militærteknologien. Den osmanniske hær, som indtog Konstantinopel i 1453, rådede over det mest moderne artilleri i Europa - et artilleri man kan besigtige den dag $i$ dag uden for Topkapi-museets mure.

Tyrkerne vandt deres store sejre, ikke som en antitese til europæerne, men ved at overtage og forfine en lang række europæiske kulturelle opfindelser. Det frygtede infanteri, janitsarerne, blev rekrutteret blandt bondesønner på Balkan og trænedes jernhårdt, så det blev det bedste og mest disciplinerede infanteri i hele Europa. Kort sagt, skal man forstå det Osmanniske Riges succes, skal man ikke se det som en flok nomader fra stepperne, som væltede ind over de agrare civilisationer $\mathrm{i}$ Europa, men snarere som den anden side af den europæiske civilisation, den anden side der i sidste ende ved sit tryk skabte to andre store imperier, det habsburgske og det russiske. Disse tre imperier dominerede i realiteten europæisk politik i det meste af de vigtige århundreder mellem 1500 og 1700.

\section{Religion og national identitet}

Denne fortolkning bekræftes yderligere, hvis man undersøger nøjere, hvordan tyrkerne behandlede den ortodokse kristendom i de erobrede lande. Allerede i 1454, året efter erobringen af Konstantinopel, fik sultan Mehmed med tilnavnet erobreren indsat en samarbejdsvillig patriark Georg Scholarios med munkenavnet Gennadios.

Han var en indædt modstander af det kompromis med den katolske kirke, der var indgået ved synoden i Firenze i 1439 - som i parentes bemærket blev anledning til et yderligere skisma med skabelsen af den unierede kirke.

Et andet udtryk for samarbejdet mellem kristne og osmannere var administrationen i de sumanske fyr- 
stedømmer. I perioder blev de administreret af græske skatteforpagtere på vegne af Den Høje Port. Normalt beskrives deres indsats som blot og bar udplyndring, og de har i hvert fald efterladt sig et enormt had til alt græsk i de rumænske og bulgarske bondebefolkninger. Faktisk er hovedgrunden til at der ikke er antisemitisme i Bulgarien at vreden traditionelt er blevet rettet mod grækere. Således var der store anti-græske pogromer i Plovdiv i 1878. Også armenierne forpagtede skatteudskrivningen i stor stil, hvilket var en af årsagerne til det voldsomme folkelige had mod dem før folkedrabet på dem i 1915.

Den serbiske kirke indgik midt i 1500-tallet et kompromis med de osmanniske herskere, der tillod oprettelsen af et serbisk patriarkat i Pec. I 1557 indsatte storvesiren Mehmed Pasha Sokolovic sin broder Makarios som ortodoks ærkebiskop (en familieforbindelse der yderligere relativerer forestillingen om riget som kun undertrykkelse af de kristne på Balkan).

Denne aftale blev til gensidig gavn. Serberne genvandt nu deres religiøse selvstændighed og dominerede Balkan fra det vestlige Bulgarien til Adriaterhavet, fra Ungarn til Makedonien, mens Den Høje Port i Istanbul fik hjælp til at indkræve skatter og udskrive slaviske bondesønner til deres infanteri, den såkaldte devsirme (blodtold). Denne 'afgift' var blevet indført i begyndelsen af 1400- tallet og spillede en central rolle i det osmanniske forvaltningssystem.

Med jævne mellemrum rejste sultanens embedsmænd rundt i de kristne landsbyer på Balkan, langs sortehavskysten og det vestlige Anatolien og samlede drengebørnene sammen og tog hvert femte med sig. I Istanbul blev børnene nemlig opdraget i den muslimske tro og absolut troskab over for sultanen for at kunne indgå $\mathrm{i}$ hans administrative og militære korps - de såkaldte janitsarer, der kommer af tyrkisk jeni ceri, de nye krigere.

Systemet betød nok sorg i familierne, men frembød også mulighed for social mobilitet, idet de tvangsudskrevne slavere konverterede til islam og fik den bedst mulige uddannelse hvorved de kunne stige til samfundets højeste poster. Denne gensidige hjælp varede, afbrudt af enkelte tyrkiske nedbrændinger af serbiske helligdomme, til slutningen af 1600-tallet.

Efter habsburgernes sejre allierede det serbiske patriarkat sig med det katolske Østrig og brød med Istanbul. Da krigslykken midlertidigt vendte, flygtede patriarken Arsenije 3. i spidsen for sit folk fra Kosovo, kaldet 'det gamle Serbien', til området omkring Novi Sad i Vojvodina og Østslavonien. De fik garanteret religionsfrihed af kejser Leopold 1. og oprettede et metropolinat i den lille by Sremski Karlovci i Vojvodina. Albanske hyrder flyttede ind i de områder de forlod, og det er deres 
efterkommere der i dag udgør befolkningsflertallet i Kosovo.

\section{Osmannerne generobrer}

I 1739 lykkedes det osmannerne at generobre Valakiet, Bosnien og Serbien. Derved uddybedes skellet mellem de forskellige dele af Balkan. På den ene side de økonomisk tilbagestående, osmannisk beherskede lande, på den anden de mere velhavende, Habsburgsk regerede, som fik del i den økonomiske vækst og de administrative reformer i det øvrige østrigske kejserrige i 1700-tallet. Serberne under tyrkisk herredømme stadig det helt store flertal - begyndte på den anden side at orientere sig mod Rusland for at få hjælp i deres selvstændighedskamp mod tyrkerne og understregede derfor deres ortodokse og slaviske identitet, mens kroaterne blev mere og mere centraleuropæiske og katolsk orienterede. Men samtidig var deres bosættelser uhjælpeligt sammenblandede.

Forskellen på serbere og kroater er først og fremmest et resultat af $\varnothing$ konomiske og politiske processer i forbindelse med skabelsen af de moderne territorialstater i Central- og Sydøsteuropa, hvor der var to konkurrerende nationsbygningsprojekter, et kroatisk (katolsk) og et serbisk (ortodokst) - hvortil i dag efter borgerkrigen kommer et tredje, et bosnisk (muslimsk) kaldet bosniaker.

Udviklingen af national bevidst- hed i de nationale stater på Balkan kompliceredes yderligere af en særlig del af arven fra det Osmanniske Imperium. Ikke så meget den økonomiske stagnation, selv om den også betød noget, som det faktum at befolkningerne i det Osmanniske Rige var organiseret efter religiøse kriterier, millet-systemet. Det indebar at den serbiske ortodokse kirke kom til at spille en afgørende rolle for bestemmelsen af serbisk identitet, en rolle som var fremmed for den noget mere kosmopolitiske katolske kirke. Denne sammenhæng mellem serbiskhed og ortodoks kristendom afrundedes med etableringen af det autonome serbiske fyrstedømme i 1830 .

De muslimske befolkninger er ligeledes et resultat af disse stats- og nationsbygningsprocesser, men ikke som man måske skulle tro på grund af aktiv mission fra de islamiske tyrkiske erobreres side. Tværtimod var omvendelse af kristne undersåtter ikke i de nye herskeres snævre interesse, da den kostede dyrt i manglende skatter. Ikke-muslimske undersåtter havde fuld religionsfrihed, men var forpligtede til at betale kopskat og formueskat samt yde forskellige former for hoveriarbejde for hærene, hvilket muslimer undgik. Embedsmændene blev uddannede på særlige skoler og var i hvert fald i teorien sultanens undergivne uden mulighed for at indlede feudale opsplitningsprocesser.

Uanset hvad årsagerne end var, 
bevarede den bosniske adel ligesom adelen i Albanien og på Kreta sin jord og sine privilegier ved at konvertere til islam. På længere sigt kom denne islamisering til at skærpe de kulturelle modsætninger i Balkan-landene.

Ganske vist opgav de nyomvendte ikke deres modersmål, men udtrykte sig fortsat på serbisk (serbokroatisk), albansk eller bulgarsk. Alligevel adskilte de sig stadig mere fra de omgivende kristne befolkninger i vaner og verdenssyn, især fordi de sammen med muslimer af tyrkisk afstamning, der havde fået ret til at åbne forretninger i byerne som kompensation for deres uregelmæssige lønudbetalinger, kom til at udgøre hovedparten af bybefolkningen.

Muslimerne udgør stadig eller rettere udgjorde indtil for ganske nylig over 50 pct. af bybefolkningerne i Bosnien, altså en meget større andel end deres andel af den totale befolkning. Forskellen på en sofistikeret og kosmopolitisk bybefolkning på den ene side og en tilbagestående landbefolkning på den anden er ifølge mange iagttagere ligefrem en af årsagerne til borgerkrigens helt exceptionelt forbitrede og grusomme karakter.

\section{Det Osmanniske Rige i opløsning}

I 1800-tallet blev befolkningerne på Balkan i stigende grad inddraget i den europæiske moderniseringsproces. Kejser Napoléon samlede efter freden i Schönbrunn i 1809 dele af Kroatien, Slovenien og Dalmatien herunder Dubrovnik, der var blevet indtaget for første gang i bystatens historie af franskmændene i 1806 til én stat ved navn Provinces Illyriennes (af det romerske navn for det vestlige Balkan). Det var i dette såkaldte 'Illyriske Rige' at den første forestilling om en jugo- dvs. syd-slavisk enhed af slovenerne, kroaterne og en del serbere blev formuleret.

Denne statsdannelse varede kun fem år, men hvor kort perioden end var, kom det franske herredømme til at betyde en kraftig modernisering af samfundet med deraf følgende spændinger og modsætningsforhold. Feudalismen blev svækket med fjernelsen af adelens skatteprivilegier og ophævelse af hoveriet. Desuden ændredes skolerne, hvilket de slaviske befolkninger udnyttede til at konsolidere deres nationale sprog. Handel og håndværk blev fritaget for lavsvæsenets bindinger, og kommunikationsmidlerne blev forbedrede

Sideløbende med denne nationale vækkelse gik det Osmanniske Rige i stadig hurtigere opløsning under dobbelt pres fra den nye beskyttermagt for de ortodokse kristne, Rusland, på den ene side og Storbritannien og Frankrig på den anden side. Disse sidste ville ikke acceptere at Rusland fik magt over hele Balkan og dermed direkte adgang til Middelhavet. Som et nyt ideologisk våben i sin århundredlan- 
ge kamp mod osmannerne var Rusland begyndt at opfordre de slaviske bondebefolkninger til at gøre oprør mod tyrkerne i 'panslavismens' navn.

Rusland havde allerede i slutningen af 1400-tallet efter Konstantinopels fald overtaget værdigheden som kristenhedens 'tredje Rom', og i en tid med voksende nationalisme var det derfor nærliggende at påberåbe sig rollen som beskytter af alle rettroende slavere. Det kunne Rusland gøre så meget desto lettere, som det var gået ud af Napoléonskrigene som det europæiske fastlands ubestridt stærkeste magt.

1804 startede et serbisk oprør mod tyrkerne. Den vigtigste oprørsleder var Karadjordje Petrocic. 1817 blev Karadjordje dræbt af Milos Obrenovic, som anerkendtes af sultanen som arvefyrste af Serbien under tyrkisk overhøjhed. $1830 \mathrm{blev}$ den serbiske autonomi-ordning internationalt anerkendt, samtidig med at Grækenland blev en selvstændig stat efter stormagternes intervention i den græske frihedskrig 1821-29. I 1861 proklameredes en selvstændig rumænsk stat under kong Alexandru Cuza, hvilket igen opildnede andre kristne folkeslag til at prøve lykken. I 1875 brød et serbisk bondeoprør ud i Hercegovina, som hurtigt bredte sig til Bosnien og til kroaterne i Bosnien-Hercegovina.

Opstanden inspirerede også grækerne på Kreta og i Thessalien og bulgarerne til at gøre oprør. Uroen fik først Serbien og Montenegro, så Rusland til at erklære osmannerne krig, hvilket efter et halvt års forbitrede kampe i Bulgarien førte til at tsar Alexander 2. i 1878 dikterede freden i San Stefano. Blandt bestemmelserne var anerkendelsen af Bosnien-Hercegovinas autonomi under Østrig-Ungarn og oprettelsen af et Storbulgarien med en grænsedragning som Bulgarien lige siden har påberåbt sig som den eneste retfærdige. Selv om Serbien havde lidt militært nederlag til tyrkerne, havde det håbet på territorielle udvidelser og chokeredes derfor, da det så godt som intet fik af byttet. Bulgarien tegnede nu til at blive den dominerende stat på Balkan.

Denne nye russiske orden i Sydøsteuropa fik imidlertid de øvrige stormagter til at reagere, som de havde gjort tidligere under Krim-krigen 1854-56. Ikke fordi de ønskede at redde 'Europas syge mand' som det Osmanniske Rige nu stadig oftere blev kaldt, men fordi de selv ville have del i byttet. Storbritannien sendte en flåde til Konstantinopel, mens Østrig-Ungarn truede med krig. Berlin-kongressen i 1878 blev et betydningsfuldt skridt på vejen til skabelsen af nationalstater på Balkan. Rumænien, Serbien og Montenegro slap fri fra deres formelle underordning under sultanen og blev fuldt selvstændige stater på linje med Grækenland. Serbien udråbtes til kongerige i 1882. Montenegro havde været et reelt uafhængigt fyr- 
ste-bispedømme indtil 1860, idet embedet gik i arv inden for familien Njegos.

Først i 1908 blev Bulgarien et helt selvstændigt kongerige. Serbien fik en beskeden forøgelse, mens Montenegro fik sit område fordoblet i form af opfyldelsen af et længe næret ønske om adgang til havet. Bessarabien tilfaldt Rusland, mens Østrig-Ungarn fik overdraget administrationen af Bosnien-Hercegovina med hovedstaden Sarajevo samtidig med at det besatte Sandjak Novi Pazar i det nuværende Serbien.

Bosnien-Hercegovina kom til at skabe store problemer for $\emptyset$ strigUngarn især efter landet blev formelt annekteret i 1908. Næsten to millioner serbokroater af katolsk, ortodoks og muslimsk tro blev dermed indlemmet i et imperium, hvor slavernes nationale rettigheder i forvejen blev ignoreret.

Ganske vist blev provinsen administreret i fællesskab af Ungarn og $\emptyset$ strig af dobbeltmonarkiets finansminister i Wien, så Bosnien undgik den hårdhændede magyariseringspolitik, der prægede resten af den ungarske rigshalvdel. Men især de bosniske serbere var utilfredse og så hen til kongeriget Serbien som deres beskytter, især efter sejre i 1 . og 2. Balkankrig mod tyrkerne og bulgarerne 1912-13.

Bulgarien og Serbien havde aftalt at dele Makedonien, hvor et albansk oprør mod ungtyrkernes osmanniserings-politik havde svækket tyrkerne alvorligt. Serberne skulle have Nordalbanien og dermed den attråede adgang til havet, mens Bulgarien skulle have størstedelen af det nuværende Makedonien. Grækenland og Montenegro sluttede sig til koalitionen, der derefter åbnede fjendtlighederne med et ultimatum til det tyrkiske rige, hvor ungtyrkiske officerer havde taget magten i 1908 og indledt en modernisering for at redde det multinationale rige.

Sejren var hurtigt hjemme, da de forenede Balkan-hære var veludrustede og dobbelt så mange som tyrkerne. Der blev indkaldt til en fredskonference i London. Her splittedes sejrherrerne, især på grund af Bulgariens territorialkrav; det ønskede stadig San Stefano-traktatens grænser. Bulgarien forsøgte sig med et overraskelsesangreb på Serbien, hvilket fik rumænerne og tyrkerne til at blande sig på serbernes og grækernes side.

Stillet over for dette pres måtte Bulgarien kapitulere efter 14 dages kamp. Denne krig mellem serberne, støttet af Rusland og bevæbnet af Frankrig, på den ene side og Bulgarien, støttet af Østrig-Ungarn og udrustet af Tyskland, på den anden, skulle vise sig at være en generalprøve på Første Verdenskrig.

Med freden i 1913 var det praktisk talt slut på den osmanniske tilstedeværelse i Europa. Bulgarien fik det vestlige Trakien og dermed adgang til Middelhavet, Grækenland det meste af Makedonien, mens Albani- 
en til de krigsførende staters store overraskelse blev en selvstændig stat først og fremmest for at hindre Serbien i at få adgang til havet.

Serbien var alligevel den store sejrherre med en næsten fordobling af sit territorium i form af indlemmelsen af det vestlige Makedonien og Sandjak Novi Pazar. Dette sidste havde Østrig-Ungarn forladt i 1908 som modydelse for indlemmelsen af Bosnien-Hercegovina. Således fik Serbien og Montenegro omsider fælles grænse og kunne derfor samarbejde militært, noget $\emptyset$ strig-Ungarn havde modarbejdet $i$ årevis. Den nye, selvsikre serbiske stat stræbte efter at samle alle sydslavere om sig, og mange begyndte at kalde den nye stat for 'Balkans Piemonte' med en hentydning til den stat, der et halvt århundrede tidligere havde samlet Italien.

Det Osmanniske Rige blev sønderlemmet ved Sèvres-traktaten af 10 . august 1920 (Balkan delen af Versailles-freden) og opdelt i en række europæiske protektorater, herunder et græsk. Grækenland havde fået overdraget Smyrna (Izmir) med en stor græsktalende befolkning og besatte med denne by som udgangspunkt det vestlige Anatolien. Det provokerede en national tyrkisk reaktion.

\section{Den store folkeflytning}

Det markerede begyndelsen til den første store folkeflytning på Balkan.
Knap to millioner såkaldte 'grækere', dvs. ortodokse blev fordrevet fra Anatolien og den europæiske del af Tyrkiet, mens godt 700.000 'tyrkere', dvs. muslimer, blev sendt den anden vej. Trods international overvågning fra Folkeforbundet omkom i hundredtusindvis af mennesker i processen. Resultatet var at hvor den kristne befolkning i 1910 havde været på 2,4 millioner, var der i 1923 kun 400.000 kristne ('grækere') tilbage i Tyrkiet.

Denne første internationalt overvågede 'etniske udrensning' medførte et had og en bitterhed mellem de to stater, som endnu langtfra er overvundet. Samtidig medførte den en social destabilisering først og fremmest i det mindre Grækenland, der resulterede i to militærdiktaturer henholdsvis 1936-41 og 1967-74 og en forbitret borgerkrig mellem 1944 og 1949, der især førtes i den nordlige del af landet op mod Albanien og Makedonien, hvor den kommunistiske bevægelse fik støtte fra Titos Jugoslavien, indtil 1949 da grænsen blev lukket.

Ved Lausanne-traktaten 24. juli 1923 anerkendte stormagterne Tyrkiets selvstændighed, og i april 1924 blev kalifatet afskaffet. Dermed var Tyrkiet endegyldigt en sekulær republik efter vestligt forbillede med nogenlunde sikre grænser.

I en vis forstand er Tyrkiet den officielle efterfølgerstat til det Osmanniske Rige, men har brudt med dettes multinationale karakter til fordel 
for en nationalstat. Men det gør i hvert fald ikke Tyrkiet mindre 'europæisk' end de andre nationale efterfølgerstater på Balkan, Grækenland, Bulgarien, Rumænien, Albanien og Jugoslavien. Alle disse lande har forsøgt at skabe homogene nationalstater på basis af en dominerende befolkningsgruppe og én religion, og ingen af dem kan siges at være meget mere succesfulde end Tyrkiet.

Den tyrkiske stat har været præget af både styrker og svagheder placeret som den er midt mellem Europa og Nærorienten, mellem islam og en sekulariseret republik, mellem moderne industri og traditionelt bondesamfund.

Tyrkerne vedkender sig arven fra osmannerne men ikke gælden. Grækerne derimod har lige fra begyndelsen af 1800-tallet og den meget romantiserede græske frihedskrig i 1820'erne fremstillet sig selv som den klassisk kristne, europæiske og demokratiske antitese til de grumme 'asiatiske' tyrkere. Efter oprettelsen af den uafhængige græske stat i 1830 levede et overvældende flertal af grækerne fortsat under osmannisk herredømme, idet mindst to tredjedele af samtlige græsktalende på Balkan, i Anatolien og Mellemøsten var undersåtter under sultanen.

Græske politikere og det græske militær opfattede den nye statsdannelse som første led i en fortsat proces, der først var afsluttet når den sidste 'græker' var blevet borger i den nye stat. Idéen om en selvstændig græesk stat var først og fremmest undfanget i det græske samfund i den russiske sortehavsby Odessa, hvor vestlige oplysningsidéer og forestillinger om national identitet havde slået rod. Men da alle nationale programmer forudsætter en tæt forbindelse mellem territorium, folk og sprog var det nødvendigt at etablere staten på den gamle 'hellige' jord - på nøjagtig samme måde som det jødiske nationale program, zionismen, ikke kunne udfolde sig $\mathrm{i}$ det Østeuropa hvor idéen var undfanget på linje med andre nationale programmer, men måtte finde fodfæste i Palæstina.

Den ungtyrkiske revolution i 1908 indledte en national omdefinering af grundlaget for det Osmanniske Rige. Reformer var strengt nødvendige, men den tyrkisk-nationale omorientering fik den ortodokse befolkning til i vid udstrækning at bekende sig som nationale grækere. Det faldt sammen med en vellykket græsk militær indsats mellem 1912 og 1922. Men trods denne tilsyneladende succes og en vis nybesindelse på den byzantinske arv var den unge græske nationalstat ekstremt følsom over for diskussioner af grundlaget for den nationale ideologi.

Konfrontationen mellem drømmen om det evige Grækenland og den nygræske virkelighed var voldsom og ofte smertefuld med bitter skuffelse for de indfødte, der hverken gik i hvide lagner, talte om filo- 
sofi eller talte oldgræsk. Alligevel viste begejstringen for antikken sig storpolitisk virksom. Den var afgørende for at Storbritannien brød med sin traditionelle protyrkiske politik i Orienten og sammen med Frankrig intervenerede i befrielseskrigen i 1827.

Samme antik-begejstring lå formodentlig ligeledes bag EF's ikke alt for gennemtænkte accept af Grækenland som fuldgyldigt medlem i 1981 og siden optagelse i ØMU'en. Især i Storbritannien er denne opfattelse blevet formuleret eksplicit af politikere og embedsmænd, sandsynligvis pga. den store rolle læsningen af græske klassikere spillede indtil for ganske nylig. I debatten i det britiske underhus om ratifikationen af traktaten om græsk medlemskab udtalte udenrigsministeren at Grækenlands indtræden var "a fitting repayment by the Europe of today of the cultural and political debt that we all owe to a Greek heritage almost three thousand years old" (citeret efter Clogg 1992, 2).

Heldigt nok for Grækenland har erindringen om det nazistiske Tysklands begejstring for 'græske' dyder - dog primært dem hos det militaristiske Sparta, i mindre grad dyderne hos det demokratiske Athen - ikke fæstnet sig i den kollektive europæiske bevidsthed. Historiske myter er en helt central ingrediens i den usikre moderne græske identitet mellem Balkan, Europa, Byzans og antikken.

\section{Græsk-serbiske fællestræk}

Først godt hundrede års krige, systematisk national indoktrinering og oprettelsen af en national græsk-ortodoks kirke i 1833 i konkurrence med det universalistiske patriarkat i Istanbul har skabt nutidens græske minination, der er fyldt af mindreværdskomplekser og aggressioner mod alle naboerne, som de da også konstant har været i konflikt med. Eneste undtagelse er serberne, som grækerne deler mange kollektiv-psykologiske træk med. Senest blev denne alliance demonstreret under krigen i det forhenværende Jugoslavien.

Tyrkerne er ikke skyldfri, bestemt ikke. Men tilsammen udgør de to nationer en farlig og virulent konstellation, som det er meget vanskelig at bringe til fred og forsoning. Fristelsen for populistiske og magtbegærlige politikere til at mobilisere hadet for selv at komme til magten har sjældent været til at modstå. Men den primære grund til hadet er at de ligner hinanden til forveksling.

Som før nævnt er Bulgarien også en osmannisk efterfølgerstat med et kompliceret forhold til sin fortid. En strålende middelalderhistorie blev efterfulgt af et meget direkte herredømme af tyrkiske godsejere.

Disse fremstilles altid som grusomme og vilkårlige, men var muligvis mindre krævende end deres kristne forgængere. Hvordan skal man ellers forklare at så mange kristne gik 
over til islam i Bulgarien foruden i Albanien, Bosnien og på Kreta? Eksistensen af et muslimsk såkaldt 'tyrkisk' mindretal i Bulgarien kom til omverdenens kendskab i 1980'erne, da en tvangsbulgarisering førte til at det såkaldte 'tyrkiske' mindretal på over en million - ud af en total befolkning på 9 millioner - begyndte at udvandre til Tyrkiet i protest mod at de blev tvunget til at udskifte deres efternavne med bulgarske. Indtil da havde mange af dem været registreret som sigøjnere! De fleste er i mellemtiden vendt tilbage, og den direkte forfølgelse er holdt op.

I 1800-tallet rettede bondebefolkningens radikale antikapitalisme sig især mod grækerne, der sad på størstedelen af handelen i byerne, selv om de kun udgjorde knap 2 pct. af den totale befolkning. Det kom til voldsomme optøjer og massemord på grækere især i den gamle hovedby Plovdiv, der dengang helt dominerede over den nuværende hovedstad Sofia, som er en relativt sen opfindelse, placeret i den yderste vestlige del af landet kun $50 \mathrm{~km}$ fra grænsen til det Makedonien bulgarerne traditionelt har opfattet som 'Vestbulgarien'.

Bulgarien blev etableret som selvstændig stat med russisk støtte efter krigen i 1878, men fik som led i magtbalancen mellem stormagterne den tyske prins Alexander von Battenberg til konge. 1885 indlemmede fyrst Alexander Østrumelien omkring Plovdiv syd for Balkan-bjerge- ne og beholdt det trods russisk modstand.

Bulgariens første ministerpræsident, Stefan Stambolov, kaldes ofte for Bulgariens Bismarck. Dermed hentydes til hans betydning for skabelsen af en stærk hær, der i den 1 . Balkankrig 1912 besejrede tyrkerne og i den 2. Balkankrig næsten klarede sig mod en koalition af alle naboerne. Men kun næsten, med det resultat at de andre delte Bulgariens erobringer og reducerede det til en lille, revanchistisk stat, der siden ved enhver lejlighed har søgt at revidere grænserne til fordel for sig selv i erindring om det store middelalderlige rige, som det ikke er mere.

Stambolov gennemførte også den første industrialisering af landet, men udviklede sig efterhånden til en autoritær diktator i stil med den kommunistiske leder Todor Sjivkov. Denne blev i 1989 afsat af sine egne og levede siden i husarrest i en af sine talrige pragtvillaer hvor han udsendte et forsvarsskrift i typisk kommunistisk papstil med den hensigt at retfærdiggøre sig og beklage sig over den 'uret' der overgik ham da han blev afsat af Centralkomitéen.

Det gik ham langt bedre end Stambolov der lagde sig ud med de ekstremistiske makedonske nationalister i organisationen IMRO (på makedonsk Vatreshna MakedonskaRevolutsionna Organizatsiya, på bulgarsk Vutreshnata Makedono-Odrinska Revolutsionna organizatsiya, dvs. den Indre Makedonske Revolu- 
tionære Organisation) og til sidst blev myrdet af disse i 1895 , svigtet af alle sine gamle støtter.

Stambolov blev efter flere mellemspil efterfulgt af en radikal bondeleder Alexandûr Stamboliski, der byggede sin magt på den store klasse af egalitært indstillede bønder, lidt i stil med den klasse der i modsætning til traditionerne i Rumænien og Albanien har muliggjort demokratiet i Tyrkiet. Bulgarien har imidlertid ikke været så heldig som Tyrkiet, især pga. utilfredsstillede territoriale krav og udenlandsk intervention.

Stamboliski blev myrdet på endnu mere bestialsk vis end Stambolov af den makedonske terroristorganisation IMRO, der har ansvaret for en lang række af århundredets mest spektakulære politiske mord. Med passiv støtte fra det traditionelle establishment torturerede IMRO den demokratiske bondepolitiker og endte med at 'skære de hænder af der havde skrevet under på fredstraktaten' efter Første Verdenskrig, som havde kostet Bulgarien alle tidligere gevinster, herunder Vesttrakien der gik til Grækenland, således at Bulgarien mistede den efterstræbte direkte adgang til Ægæerhavet uden om det tyrkisk kontrollerede Bosporus.

\section{Konklusion}

Af de her beskrevne årsager bør så- vel Grækenland som Tyrkiet regnes med til 'Balkan', hvis man opfatter betegnelsen politisk, historisk og kulturelt og ikke blot geografisk. De to lande afviser ganske vist i deres egen selvforståelse at høre med. Men netop derved ligner de hinanden og de øvrige 'Balkan'-lande. Grækenland vakler imellem arven fra det klassiske Grækenland og det kristne Byzans, mens tyrkerne vakler mellem den osmanniske arv, arven fra de centralasiatiske stepper, et islamisk-mellemøstligt tilhørsforhold og tilslutning til en ret autoritær udgave af de europæiske værdier.

Fælles for alle landene på Balkan er en arv fra det Byzantinske og det Osmanniske Rige. Den kan man vælge at kalde 'byzantinsk', 'caesareopapisme' alt efter smag. Givet er det at det er i denne historiske arv man skal søge baggrunden for de fælles træk der karakteriserer denne del af Europa. Om det vil vare ved er op til valg som befolkningerne og deres ledere træffer.

I øjeblikket synes de glimrende at leve op til de værste fordomme. Men der er andre potentialer i historien.

Uffe Østergård er professor ved CBS, International Center for Business and Politics.

Litteraturlisten til artiklen kan fås ved at sende en mail til brita@udenrigs.dk 